\title{
EVALUASI PENGHITUNGAN PAJAK PENGHASILAN PASAL 21 (STUDI KASUS PADA DINAS PUPR PROVINSI MALUKU UTARA)
}

\author{
Tiara Ningrum ${ }^{1}$, Ventje Ilat ${ }^{2}$, Winston Pontoh $^{3}$ \\ ${ }^{1,2,3}$ Jurusan Akuntansi, Fakultas Ekonomi dan Bisnis, Universitas Sam Ratulangi, Jl. Kampus Bahu, Manado, \\ 95115, Indonesia
}

E-mail: tiara.95ningrum@gmail.com

\begin{abstract}
In improving people's welfare and national development, the government requires regular acceptance. In the state budget (APBN) the biggest source of revenue is from the tax sector. Tax is a mandatory contribution that is imposed on every tax payer on the object it has and the result are submitted to the government. North Maluku Public Works and Public Housing Office is one on the regional apparatus that has a number of employees with the specification of civil servants (state civil servants) and regional honorary employees, so that it has great potential in paying taxes, especially article 21 of the income tax. in addition, the office of Public Works and Public Housing in North Maluku Province also has the potential to cause irregularities in the calculation of income tax due to differences in views on the Income Tax Law. this is the research reference with the title "Evaluation Of Article 21 Income Tax Calculation For Civil Servants in the Public Works and Public Housing Agency of North Maluku Provinces". The purpose of this study is to determine the Calculation of Income Tax Article 21 for Civil Servants in the Public Works and Public Housing Office of North Maluku Province has been appropriate and in accordance with applicable laws and regulation. The method used in this research is quantitative descriptive method. Calculation of Income Tax Article 21 of civil servants salaries at the Department Public Works and Public Housing in North Maluku has been carried out correctly and in accordance with the provisions of the applicable Taxation Law.
\end{abstract}

Keywords: income tax; North Maluku; income tax Article 21; tax evaluation

\section{PENDAHULUAN}

Perkembangan pembangunan di Indonesia tidak lepas dari peranan pemerintah yang memberikan kesempatan pada berbagai pihak untuk mengembangkan diri seluas-luasnya demi menunjang sasaran pembangunan nasional yaitu, pemerataan pertumbuhan ekonomi, dan stabilitas nasional untuk meningkatkan kesejahteraan rakyat. Pajak yang berlaku bagi karyawan adalah Pajak Penghasilan Pasal 21 yang merupakan pajak yang dikenakan kepada wajib pajak orang pribadi yang memperoleh penghasilan. Bagi Negara, pajak merupakan sumber penerimaan penting yang akan digunakan untuk membiayai Negara baik pengeluaran rutin maupun pengeluaran pembangunan. Dari segi ekonomi, pajak merupakan pemindahan sumber daya dari perusahaan ke sektor publik. Pemindahan sumber daya tersebut akan mempengaruhi daya beli atau kemampuan belanja perusahaan. Pajak merupakan sumber daya yang dapat dipengaruhi sesuai dengan perkembangan ekonomi yang nantinya akan dikembalikan lagi ke masyarakat dalam bentuk lain.

Dinas Pekerjaan Umum dan Perumahan Rakyat Maluku Utara merupakan salah satu perangkat daerah yang mempunyai jumlah pegawai dengan spesifikasi pegawai negeri sipil (aparatur sipil negara) dan pegawai honorer daerah, sehingga memiliki potensi yang besar dalam membayar pajak khususnya Pajak Penghasilan Pasal 21. 


\section{TINJAUAN PUSTAKA}

Akuntansi adalah urutan proses kegiatan pencatatan, penggolongan, peringkasan dan penyajian dengan cara tertentu atas transaksi keuangan yang terjadi dalam perusahaan atau organisasi serta penafsiran terhadap hasilnya. Menurut Haryono (2011), akuntansi dapat dirumuskan dari dua sudut pandang yaitu definisi dari sudut pemakai jasa akuntan dan dari sudut proses kegiatannya. Akuntansi yang dilaksanakan oleh perusahaan atau organisasi pada umumnya mengacu pada Prinsip Akuntansi atau Standar Akuntansi Keuangan (SAK), dalam pengertian ini disebut akuntansi komersial. Akuntansi juga dapat diartikan sebagai seperangkat pengetahuan dan fungsi yang berkepentingan dengan masalah pengadaan, pengesahan, pencatatan, pengklasifikasian, pemrosesan, peringkasan, penganalisisan, penginterpretasian, dan penyajian secara sistematik informasi yang dapat dipercaya dan berdaya guna tentang transaksi dan kejadian yang bersifat keuangan yang diperlukan dalam pengelolaan dan pengoperasian suatu unit usaha dan yang diperlukan untuk dasar penyusunan laporan yang harus disampaikan untuk memenuhi pertanggungjawaban pengurusan keuangan dan lainnya (Suwardjono, 2014).

Undang-Undang Republik Indonesia No. 16 Tahun 2009 tentang Ketentuan Umum dan Tata Cara Perpajakan menyebutkan bahwa pajak adalah kontribusi wajib kepada Negara yang terutang oleh orang pribadi atau badan yang bersifat memaksa berdasarkan UndangUndang, dengan tidak mendapatkan imbalan secara langsung dan digunakan untuk keperluan Negara guna kemakmuran rakyat. Pajak adalah iuran kepada negara yang dapat dipaksakan yang terutang oleh yang wajib membayarnya menurut peraturan perundangan dengan tidak mendapat prestasi kembali secara langsung untuk membiayai pengeluaran publik (Brotodiharjo, 2013:2). Menurut Soemitro dalam Mardiasmo (2016), pajak adalah iuran rakyat kepada kas negara berdasarkan undang-undang (yang dapat dipaksakan) dengan tiada mendapat jasa timbal (kontraprestasi) yang langsung dapat ditunjukan dan yang digunakan untuk membayar pengeluaran umum. Menurut Mardiasmo (2016:4), fungsi pajak terdiri dari fungsi anggaran (budgetair) dan fungsi mengatur (regulation). Menurut Mardiasmo (2011:7), sistem pemungutan pajak adalah official assessment system, self assessment system, dan withholding system.

Undang-Undang Pajak Penghasilan mengatur pengenaan pajak penghasilan terhadap subjek pajak berkenaan dengan penghasilan yang diterima atau diperolehnya dalam tahun pajak. Subjek Pajak tersebut dikenai pajak apabila menerima atau memperoleh penghasilan. Subjek Pajak yang menerima atau memperoleh penghasilan, dalam Undang-Undang $\mathrm{PPh}$ disebut Wajib Pajak. Wajib Pajak dikenai pajak atas penghasilan yang diterima atau diperolehnya selama satu tahun pajak atau dapat pula dikenai pajak untuk penghasilan dalam bagian tahun pajak apabila kewajiban pajak subjektifnya dimulai atau berakhir dalam tahun pajak (Mardiasmo,2011:135). Menurut Mardiasmo (2011:136), terdapat beberapa subjek pajak penghasilan, antara lain adalah orang pribadi, warisan (yang belum terbagi sebagai satu kesatuan menggantikan yang berhak), badan dan bentuk usaha tetap. Subjek pajak atas pajak penghasilan adalah segala sesuatu yang mempunyai potensi untuk memperoleh penghasilan dan menjadi sasaran untuk dikenakan Pajak Penghasilan (Waluyo, 2014:75). Berdasarkan Pasal 2 ayat (1) UU Nomor 36 Tahun 2008, yang menjadi Subjek Pajak adalah orang pribadi, warisan yang belum terbagi sebagai kesatuan, menggantikan yang berhak, badan, dan Badan Usaha Tetap (BUT).

Menurut Undang-Undang Nomor 36 Tahun 2008, Pajak Penghasilan Pasal 21 adalah pajak atas penghasilan berupa gaji, upah, honorarium, tunjangan dan pembayaran lain dengan nama dan dalam bentuk apapun sehubungan dengan pekerjaan atau jabatan, jasa dan kegiatan yang dilakukan oleh orang pribadi. Subjek pajak dalam negeri, sebagaimana dimaksud dalam Pasal 21 Undang-Undang Pajak Penghasilan. Pembayaran penghasilan yang wajib dipotong PPh Pasal 21 oleh bendahara pemerintah antara lain adalah pembayaran atas gaji, tunjangan, 
honorarium, upah, uang makan dan pembayaran lainnya (tidak termasuk pembayaran biaya perjalanan dinas), baik kepada pegawai maupun bukan pegawai., apabila penerima penghasilan adalah selain Pejabat Negara, PNS, Anggota TNI/POLRI dan pensiunannya, pemotongan $\mathrm{PPh}$ Pasal 21 mengacu pada ketentuan umum pemotongan PPh Pasal 21. Peraturan terkait pelaksanaan pemotongan $\mathrm{PPh}$ Pasal 21 terakhir diatur dalam Peraturan Direktur Jenderal (Perdirjen) Pajak Nomor PER-32/PJ/2015. Menurut Mardiasmo (2016:171), penerima penghasilan yang dipotong pajak penghasilan Pasal 21 adalah orang pribadi. Menurut Mardiasmo (2011:32), yang menjadi objek pajak adalah yang memiliki penghasilan atau setiap tambahan kemampuan ekonomis yang diterima atau diperoleh Wajib Pajak, baik yang berasal dari Indonesia maupun dari luar Indonesia, yang dapat dipakai untuk konsumsi atau menambah kekayaan Wajib Pajak yang bersangkutan, dengan nama dan bentuk apapun. Direktorat Jenderal Pajak telah menerbitkan Peraturan Direktorat Jenderal Pajak Nomor PER-31/PJ/2009 tentang pedoman teknis tata cara pemotongan, penyetoran dan pelaporan Pajak Penghasilan Pasal 21 sehubungan dengan pekerjaan, jasa dan kegiatan orang pribadi. Peraturan tersebut merupakan petunjuk pelaksanaan dari Menteri Keuangan252/PMK.03/2008, tentang petunjuk pemotongan atas penghasilan sehubungan dengan pekerjaan, jasa dan kegiatan orang pribadi.

Lumintang et al. (2014) menemukan bahwa Dinas Sosial Provinsi Sulawesi Utara sudah menerapkan pelaksanaan sistem perhitungan PPh Pasal 21 sesuai dengan UU Perpajakan Nomor 36 tahun 2008. Mumu et al. (2018) menemukan bahwa penghasilan selain gaji wajib dikenakan atau dilakukan pemotongan Pajak, khususnya Pajak Penghasilan ( $\mathrm{PPh})$ Pasal 21. Rondonuwu et al. (2017) menemukan bahwa THR wajib masuk dalam penghitungan Pajak Penghasilan Pasal 21 yang dipotong perusahaan terhadap karyawan. Woruntu et al. (2015) menemukan bahwa PPh Pasal 21 atas 25 orang Guru PNS yang bekerja di Dinas Pendidikan Pemuda dan Olahraga Kabupaten Minahasa khususnya pada tiga sekolah yang ada di kecamatan Eris untuk TKD pegawai, telah sesuai dengan penerapan menurut Peraturan Pemerintah No. 80 Tahun 2010, karena tidak terdapat selisih dalam perhitungan. Tindagi dan Morasa (2014) menunjukkan bahwa perhitungan PPh yang dilakukan oleh objek penelitian belum sesuai dengan Undang-Undang Perpajakan Nomor 36 Tahun 2008. Watung (2013) menemukan bahwa PT. Cipta Daya Nusantara telah melakukan perhitungan, pemotongan, serta pelaporan PPh 21 sesuai Undang Undang Perpajakan Nomor 36 tahun 2008. Dewi dan Ulupui (2014) menemukan bahwa pajak bukan merupakan faktor dari sebuah perusahaan untuk melakukan manajemen laba.

\section{METODE PENELITIAN}

Jenis penelitian yang dilakukan adalah studi kasus. Penelitian ini dilakukan terhadap objek tertentu disertai dengan pengumpulan data selama periode tertentu, kemudian data tersebut dievaluasi sehingga dapat memberikan kesimpulan yang cukup jelas atas objek yang diteliti. Objek dari penelitian ini adalah Dinas Pekerjaan Umum dan Perumahan Rakyat Provinsi Maluku Utara. Jenis data yang digunakan dalam penelitian ini yaitu data kuantitatif yaitu data yang disajikan dalam bentuk angka-angka atau bilangan yang dapat dihitung dan dapat dibandingkan dari satu data dengan data yang lainnya. Data-data tersebut berupa daftar penghasilan Pegawai Negeri Sipil dan perhitungan Pajak Penghasilan (PPh) Pasal 21.

Banyaknya jumlah pegawai negeri sipil dan lebih dari satu jenis pegawai yang bekerja memunculkan kompleksitas pelaksanaan pemotongan PPh Pasal 21 yang menarik untuk dikaji lebih mendalam khususnya untuk pegawai negeri sipil. Sumber data dalam penelitian ini, yaitu: (1) data primer, yaitu data yang diperoleh langsung oleh penulis dari objek penelitian dengan cara wawancara dan data yang diambil dari perusahaan seperti daftar penghasilan pegawai negeri sipil dan perhitungan Pajak Penghasilan Pasal 21; dan (2) data sekunder, yaitu data yang berasal dari sumber atau pengamatan lain, contohnya buku-buku 
literatur yang digunakan sebagai acuan, jurnal penelitian, Undang-Undang dan peraturan tentang Pajak Penghasilan (PPh) Pasal 21, serta data pendukung lainnya.

Dalam penelitian ini, metode yang dilakukan dalam usaha mengumpulkan data dan informasi, yaitu penelitian lapangan (field researd method). Penelitian lapangan dilakukan dengan cara wawancara (interview), yaitu dengan cara mewawancarai pimpinan untuk mendapatkan data penghasilan pegawai tetap yang benar dan jelas yaitu mengenai bagaimana mekanisme perhitungan dan pemotongan PPh Pasal 21 yang digunakan pada Dinas Pekerjaan Umum dan Perumahan Rakyat Maluku Utara berdasarkan dengan memperhatikan status dari masing-masing pegawai. Metode analisis data yang digunakan dalam penelitian ini adalah metode deskriptif, yaitu membahas masalah dengan cara mengumpulkan, menguraikan, menghitung dan membandingkan suatu keadaan serta menjelaskan suatu keadaan sehingga dapat ditarik kesimpulan yang meliputi Perhitungan Pajak Penghasilan ( $\mathrm{PPh})$ Pasal 21 pada pegawai tetap di Dinas Pekerjaan Umum dan Perumahan Rakyat Provinsi Maluku Utara.

\section{HASIL ANALISIS DAN PEMBAHASAN}

\subsection{Hasil penelitian}

Peranan pegawai adalah keterlibatan mereka dalam sebuah perencanaan, sistem, proses dengan segala kegiatannya dalam usaha mencapai hasil guna dan daya guna yang efektif dan efisien, sesuai dengan harapan perusahaan yang bersangkutan. Tabel 1 menyajikan data jumlah PNS, golongan/pangkat dan keluarga pada Dinas Pekerjaan Umum dan Perumahan Rakyat Maluku Utara.

Tabel 1. Daftar pangkat, golongan dan keluarga pada Dinas Pekerjaan Umum dan Perumahan Rakyat Maluku Utara

\begin{tabular}{cccccc}
\hline No & Golongan & Pegawai & Isteri/Suami & Anak & Jumlah \\
\hline 1 & IV & 15 & 11 & 22 & 48 \\
2 & III & 74 & 69 & 103 & 246 \\
3 & II & 32 & 28 & 21 & 81 \\
4 & I & 0 & 0 & 0 & 0 \\
\hline & JUMLAH & $\mathbf{1 2 1}$ & $\mathbf{1 0 8}$ & $\mathbf{1 4 6}$ & $\mathbf{3 7 5}$ \\
\hline
\end{tabular}

Sumber: Dinas Pekerjaan Umum dan Perumahan Rakyat Maluku Utara, 2018

Pemotongan gaji pegawai Dinas Pekerjaan Umum dan Perumahan Rakyat Maluku Utara untuk mempermudah pegawai Dinas Pekerjaan Umum dan Perumahan Rakyat Maluku Utara dalam hal pembayaran PPh terutang, maka Bendaharawan Dinas Pekerjaan Umum dan Perumahan Rakyat Maluku Utara langsung memotong gaji pegawainya. Tabel 2 menyajikan hasil pemotongan pajak penghasilan setiap bulan sesuai dengan jumlah pajak yang terutang pada masing-masing pegawai. 
Tabel 2. Hasil pemotongan PPh Pasal 21

\begin{tabular}{ccc}
\hline No & Golongan & Dinas PU dan PR \\
\hline 1 & II & 71.537 \\
2 & II & 82.593 \\
3 & II & 69.773 \\
4 & II & 53.119 \\
5 & II & 47.615 \\
6 & III & 162.521 \\
7 & III & 143.791 \\
8 & III & 124.432 \\
9 & III & 132.542 \\
10 & III & 119.775 \\
11 & III & 151.733 \\
12 & III & 118.520 \\
13 & IV & 243.875 \\
14 & IV & 267.555 \\
15 & IV & 282.332 \\
\hline
\end{tabular}

Sumber: Dinas Pekerjaan Umum dan Perumahan Rakyat Maluku Utara, 2018

\subsection{Pembahasan}

Hasil penelitian yang dilakukan pada Dinas Pekerjaan Umum dan Perumahan Rakyat Maluku Utara atas evaluasi penerapan PPh Pasal 21 didapatkan hasil melalui perhitungan sampel pada gaji PNS kemudian melakukan perbandingan antara perhitungan dari Dinas Pekerjaan Umum dan Perumahan Rakyat Maluku Utara dengan perhitungan yang diperoleh dari hasil penelitian, sehingga diperoleh perhitungan PPh. Pasal 21 yang benar dan sesuai dengan peraturan UU Perpajakan. Tabel 3 menyajikan hasil evaluasi perhitungan PPh Pasal 21 dari penelitian ini.

Tabel 3. Evaluasi perhitungan PPh Pasal 21

\begin{tabular}{ccccc}
\hline No. & Golongan & Dinas PUPR & UU No.36 Tahun 2008 (Rp) & Selisih (Rp) \\
\hline 1 & II & 71.537 & 71.537 & - \\
2 & II & 82.593 & 82.593 & - \\
3 & II & 69.773 & 69.773 & - \\
4 & II & 53.119 & 53.119 & - \\
5 & II & 47.615 & 47.615 & - \\
6 & III & 162.521 & 162.521 & - \\
7 & III & 143.791 & 143.791 & - \\
8 & III & 124.432 & 124.432 & - \\
9 & III & 132.542 & 132.542 & - \\
10 & III & 119.775 & 119.775 & - \\
11 & III & 151.733 & 151.733 & - \\
12 & III & 118.520 & 118.520 & - \\
13 & IV & 243.875 & 243.875 & - \\
14 & IV & 267.555 & 267.555 & - \\
15 & IV & 282.332 & 282.332 & - \\
\hline
\end{tabular}

Sumber: Dinas Pekerjaan Umum dan Perumahan Rakyat Maluku Utara, 2018 


\section{KESIMPULAN DAN SARAN}

\subsection{Kesimpulan}

Kesimpulan atas penelitian ini adalah bahwa perhitungan PPh Pasal 21 gaji PNS pada Dinas Pekerjaan Umum dan Perumahan Rakyat Maluku Utara telah dilakukan dengan benar dan sesuai dengan ketentuan Undang-Undang Perpajakan yang berlaku, dimana PPh Pasal 21 dikenakan pada pegawai Dinas Pekerjaan Umum dan Perumahan Rakyat Maluku Utara adalah gaji, upah, honorarium, tunjangan istri/suami, tunjangan anak, tunjangan jabatan, tunjangan pangan, tunjangan umum.

\subsection{Saran}

Saran yang dapat diberikan kepada Dinas Pekerjaan Umum dan Perumahan Rakyat Maluku Utara:

1. Dinas Pekerjaan Umum dan Perumahan Rakyat Maluku Utara perlu adanya rincian perhitungan PPh Pasal 21 agar mempermudah masing-masing pegawai untuk mengetahui ketepatan jumlah PPh Pasal 21.

2. Penulisan tunjangan istri yang terdapat di nomenklatur daftar gaji harus diperbaiki menjadi Tunjangan Suami atau Tunjangan Istri sesuai dengan siapa diantara keduanya yang memiliki Gaji Pokok lebih tinggi.

\section{DAFTAR PUSTAKA}

Brotodiharjo, R. S. (2013). Pengantar ilmu hukum pajak. Bandung: Refika Aditama.

Dewi, L. S., \& Ulupui, I. G. K. A. (2014). Pengaruh pajak penghasilan dan asset perusahaan pada earnings management. E-Jurnal Akuntansi, 8(1), 250-259. https://ojs.unud.ac.id/index.php/Akuntansi/article/view/9569

Haryono, J. A. (2011). Dasar-dasar akuntansi. Yogyakarta: Sekolah Tinggi Ilmu Ekonomi Yogyakarta.

Lumintang, A. T., Tinangon, J. J., \& Elim, E. (2014). Evaluasi perhitungan PPh Pasal 21 Pegawai Negeri Sipil pada Dinas Sosial Provinsi Sulawesi Utara. Jurnal EMBA: Jurnal Ekonomi, Manajemen, Bisnis, dan Akuntansi, 2(2), 926-934. https://ejournal.unsrat.ac.id/index.php/emba/article/view/4439

Mardiasmo. (2011). Perpajakan Edisi Revisi 2011. Yogyakarta: Andi Offset.

Mardiasmo. (2016). Perpajakan edisi revisi 2016. Yogyakarta: Andi.

Mumu, A., Latulola, A., \& Rondonuwu, S. (2018). Ipteks perhitungan Pajak Penghasilan $(\mathrm{PPh})$ PASAL 21 untuk tambahan penghasilan Pegawai Negeri Sipil di Dinas Tenaga Kerja Kota Manado. Jurnal Ipteks Akuntansi bagi Masyarakat, 2(2), 172-176. https://doi.org/10.32400/jiam.2.02.2018.21720

Peraturan Direktorat Jenderal Pajak Nomor PER-31/PJ/2009 tentang pedoman teknis tata cara pemotongan, penyetoran dan pelaporan Pajak Penghasilan Pasal 21 sehubungan dengan pekerjaan, jasa dan kegiatan orang pribadi.

Peraturan Menteri Keuangan Nomor 252/PMK.03/2008, tentang petunjuk pemotongan atas penghasilan sehubungan dengan pekerjaan, jasa dan kegiatan orang pribadi.

Peraturan Direktur Jenderal (Perdirjen) Pajak Nomor PER-32/PJ/2015 tentang Pedoman Teknis Tata Cara Pemotongan, Penyetoran, dan Pelaporan Pajak Penghasilan Pasal 21 dan/atau Pajak Penghasilan Pasal 26 Sehubungan Dengan Pekerjaan, Jasa, dan Kegiatan Orang Pribadi

Rondonuwu, C., Elim, I., \& Pinatik, S. (2017). Analisis penerapan perhitungan dan pemotongan Pajak Penghasilan Pasal 21 Rumah Sakit Pancaran Kasih Manado. Going Concern: Jurnal Riset Akuntansi, 12(01), 48-53. https://doi.org/10.32400/gc.12.01.17136.2017 
Suwardjono. (2014). Teori akuntansi perekayasaan pelaporan keuangan, Edisi Ketiga Cetakan 8. Yogyakarta: Badan Penerbit Fakultas Ekonomi.

Tindagi, R., \& Morasa, J. (2014). Analisis perhitungan pajak penghasilan badan pada PT.

Golden Mitra Inti Perkasa. Jurnal EMBA: Jurnal Riset Ekonomi, Manajemen, Bisnis dan Akuntansi, 2(2), 1067-1076. https://ejournal.unsrat.ac.id/index.php/emba/article/view/4487

Undang-Undang Nomor 36 Tahun 2008 tentang perubahan keempat atas Undang-Undang No. 7 tahun 1983 tentang pajak penghasilan.

Waluyo, (2014). Perpajakan Indonesia. Jakarta: Salemba Empat

Watung, N. (2013). Analisis perhitungan dan penetapan Pajak Penghasilan Pasal 21 serta pelaporannya. Jurnal EMBA: Jurnal Ekonomi, Manajemen, Bisnis, dan Akuntansi, 1(3), 265-273. https://ejournal.unsrat.ac.id/index.php/emba/article/view/1735

Woruntu, R. A., Pangemanan, S., \& Kalalo, M. Y. B (2015). Analisis pemotongan dan pengenaan PPh Pasal 21 atas penghasilan yang menjadi beban APBN atau APBD atas gaji dan tunjangan kinerja daerah pegawai pada Dikpora Kabupaten Minahasa. Jurnal EMBA, Jurnal Ekonomi Manajemen Bisnis dan Akuntansi, 3(3), 1319-1329. https://ejournal.unsrat.ac.id/index.php/emba/article/view/10415 